\title{
INSTITUTIONALIZING THE SALAFI THOUGHTS BY THE STATE: THE SAUDI SALAFISM AS A CASE
}

\author{
Kardo Rached \\ Sakarya University and University of Human Development
}

\begin{abstract}
The Arab Spring, as a historical turning point in the Middle East, sparked an unparalleled explosion of violent jihadist groups, armed rebel groups, and transnational religious movements. These violent religious groups claim to advance the correct interpretation of Salafism according to their ideological principles and their interpretation of Islamic rule. To examine the nature, causes, and parties involved in a violent religious group's turbulent infrastructure, one needs to have a deep understanding of Salafism's thought and political perspective. This research, conducted using the historical-analytical method, identifies the triangular relationship between the state, its institutions, and Salafism. Our case study is the Saudi state's role in institutionalizing Salafist doctrine and construing its political behavior. This relationship has deep historical roots, but the participating entities have changed over time from friends to foes. We highlight the analogy and mechanisms used historically by the Saudi state's apparatus to design and organize Salafist thought and its political platform.
\end{abstract}

Keywords: Middle East, Saudi Arabia, state-religion relation, Islamic thoughts, Salafism, violent religious groups

DOI: https//doi.org/10.3176/tr.2021.2.05

Received 20 January 2021, accepted 14 April 2021, printed and available online 10 June 2021 


\section{Introduction}

Salafism has been a cornerstone for many past and current Sunni Islamic movements. Its ideology and political thought garnered massive attention among Middle Eastern researchers after September 11. Before those attacks, research mainly focused on different Islamic groups, such as the Muslim Brotherhood in Egypt and the Nahda movement in Tunisia, but afterwards greatly expanded its lens in terms of the groups studied and its geographic focus.

In this research, we identify the structure and fundamentals of Salafism's organizing political thought by looking at Salafism in Saudi Arabia. We chose Salafism in Saudi Arabia as our case study because modern Salafism's history and its roots go back to Muhammad ibn Abd al-Wahhab's Aqida (Islamic theology), which originated in now Saudi Arabia between 1703 and 1792 (Figure 1). Many Islamic religious leaders and scholars consider Abd al-Wahab as the father of modern Salafism (Khatab 2011). He also signed a religious-political agreement with Muhammad bin Saud to establish the Emirate of Diriyah, the first Saudi state. That deal between them resulted in a dynastic alliance and power-sharing arrangement between their families that still exists in Saudi Arabia today (Hourani 1992: 257-259).

Our goal in this research is to grasp the influence of Saudi decision-makers on the Salafist movement's institutionalization and the crystallization of its political views, in part by reviewing definitions of the decision-making process and its determinants. In our study, we focus on the Saudi state's internal and external decision-making determinants. Moreover, through its decision-making process, we learn how the Saudi state could contain the movement and use it to influence foreign and domestic actors.

Then we attempt, in chronological order, to shed light on the interdependence/ interrelationship between the Saudi state (led by the family of Saud) and the Salafist movement (represented by the Wahhabi movement), especially after the Second World War. We chose this date is because of the emergence on the international stage of the independent Saudi state. In 1945, a public meeting took place between US President Roosevelt and King Abdulaziz bin Saud, which is usually seen when Saudi Arabia emerged onto the world stage.

The post-Arab Spring era resulted in gaps in the concepts and interpretations of the Salafist movement, its histories, and orientations. In Tunisia and Egypt, intense debates arose among politicians and academics about Salafism, democracy, and the modern State. Those gaps became unmanageable when groups claiming the mantle of Salafism emerged in Egypt and Tunisia's political arenas and participated in parliamentary elections. For example, in Egypt, the newly-created Al-Nour Party was viewed as part of the Salafist movement when it participated in the 2011 postMubarak election, winning 22\% of the seats in parliament. Before the Arab-Spring, Salafist figure Emad Eddine Abdel-Ghaffour, who became a leading organizer within Al-Nour, refused to talk about politics and denied any attempt to engage in politics in the name of Salafism, but clearly changed his approach following the Arab Spring (Insight \& Analysis 2012). 
From this standpoint mentioned above, we classify the Salafist movement, its political views and its deals with the State. The questions that we try to answer can be formulated as follows: How did the Kingdom of Saudi Arabia deal with the Salafist movement? What are the effects of dealing with the Salafist movement's thoughts and political views? To what extent were Saudi decision-makers able to influence this movement's political opinions and behaviors?

Regarding the methodology of our paper, We first attempt to explain the political decision-making process in Saudi Arabia and the elements involved in forming decisions by analyzing the history of the interrelationship between the state and the Salafist movement. This analysis led to the beginning of the institutionalization of Salafist thought by King Faisal after World War II to use against his opponents, primarily the nationalists and the Nasserites. The relationship between them became healthy and robust until the beginning of Kuwait's occupation by Iraq and the issuance of the famous fatwa by the Council of senior scientists that allowed foreign forces to be present in the Kingdom.

We rely on the historical-analytical approach as a methodology for this research. Through this approach, I try to analyze the positions and variables of the Salafist movement's political views in Saudi Arabia. How did the Kingdom deal with that movement?

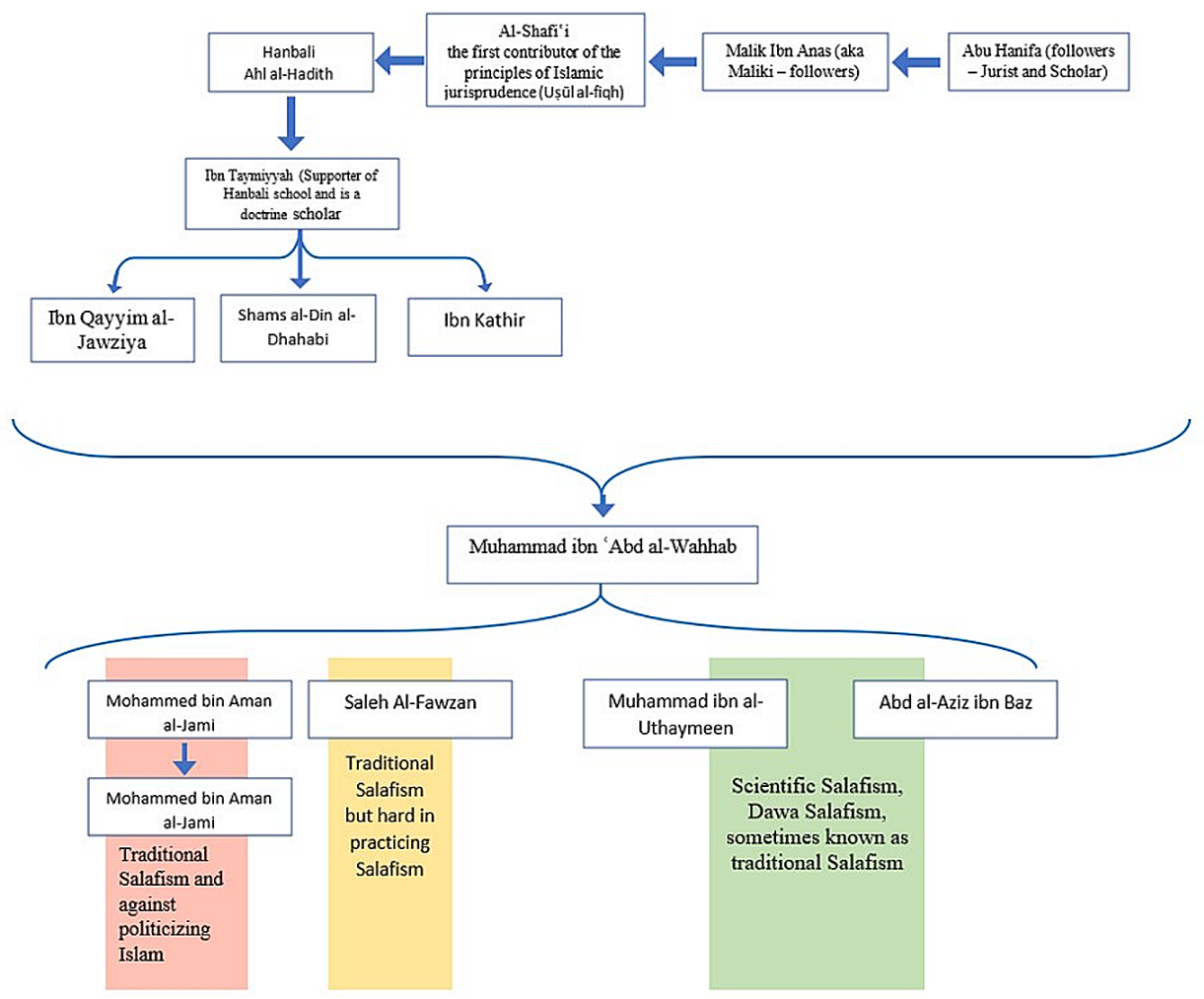

Fig. 1. Overview of the roots of Salafism in Saudi Arabia. 


\section{Part one: decision-making process in the Saudi monarchy}

The decision-making process in Saudi Arabia will be addressed from two different perspectives:

\subsection{Units/factors involved in Saudi decision-making}

In this part of the research, we try to highlight the processes involved in Saudi society's political decision-making process. We must define the decision-making process before exploring the units upon which Saudi decision-makers are building their decisions. From an academic perspective, the definition of the decision-making process can be explained in this way:

"Decision-making is defined as a process of choosing between a set of alternatives to deal with a problem or a solution to it by a group of persons, bodies or institutions, and the decision-making is expanded according to the political system of the state (Shahrour 2013)."

While Yan Xing has a more coherent definition,

decision-making refers to the process in which management subjects such as the government or the main political parties specify and select the action plan, and it is the process of selecting the direction, objectives, principles, methods, and steps of the problem. Political decision-making is the process of comparing and selecting the implementing principles, and approaches, and methods to achieve the goals in which a country's political parties, political leader, or leadership conducts practical activities for the purpose, principles, and direction of activities. The process of political decision-making is a dynamic political process related to the formation and implementation of national, political and social interest groups (Yan 2015).

According to Waleed Abdulhay, there are two broad explanations for how Gulf monarchies make decisions (Figure 2 and 3): one using internal determinants and relying on external determinants (Abdulhay et al. 2010: 35).

The internal determinants of Saudi Arabian decision-making consist of the following mechanisms (Abdulhay et al. 2010: 147-226):

1. The King: His role is dominant and central in the decision-making process. He is the Imam (religious leader), the military commander, and the judge of judges. Thus, we focus on the King as the highest executive, legislative, and judicial authority.

2. The ruling family council Conducts discussions on the most critical internal and external issues. The King has the final decision to resolve differences that arise.

3. The religious institution: Consisting of the Council of Senior Scholars, it expresses the traditional Salafist/scientific understanding and represents Islam as one of the fundamental ideological frameworks of the state. Since its establishment, the Kingdom's founder has benefited from the Wahhabi group, commonly referred to as the "Brothers" or Brothers of the Faithful" - a fanatical religious group whose 
goal is to impose the correct interpretation of Islam and use its war against its enemies.

4. Tribal sheiks: According to Yousef Mekki, the tribes are considered the Saudi state's social base. At the foundation of the Saudi state, King Saud established the National Guard using members of different tribes.

5. Army leaders: They are the protectors and servants of the two holy mosques in Mecca and Medina. The army commanders are considered mechanisms for protecting the King and the regime.

The external determinants include:

1. Mecca and Medina: The Saudi state is central to Muslims because of the two holy mosques.

2. The Saudi-US Oil Alliance: This alliance is embodied by the largest oil company in the Middle East, Saudi Aramco.

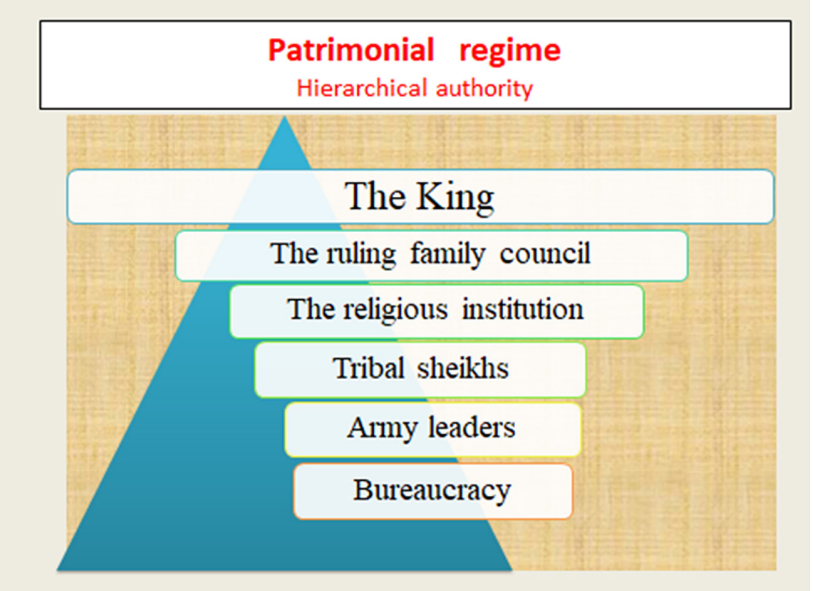

Fig. 2. An overview of the Saudi decision-making process.

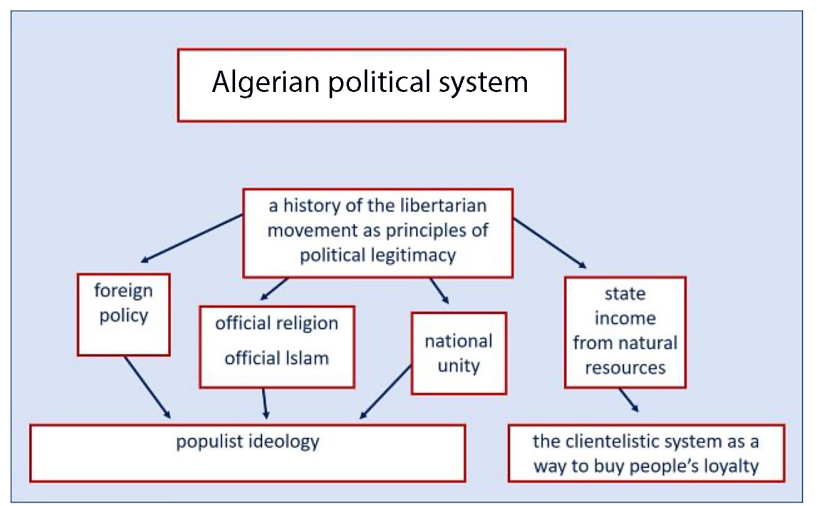

Fig. 3. An overview of the decision-making in an Arabic republic such as Algeria. 


\subsection{Solidarity}

Khaldoun Hassan Al-Naqib argues that the Saudi state's sovereign decisionmaking process is organized through solidarity. The regime tries to establish solidarity among the Gulf countries to find backing and support for its social and economic policies. Through these solidarity attempts, social forces express themselves through individual heads of state or specific recognition by the state.

The independence of the authoritarian State upon the corporations in the Gulf and the Arab Peninsula environment, and in the absence of parties representing the populace and of social systems facilitating national fusion, necessarily lead to the institutionalization of tribalism and sectarianism, just as the attainment of political independence led to the institutionalization of regionalism as opposed to pan-Arab integration. From the course of the authoritarian State, it appears that the attempt to achieve an effective monopoly on the sources of power and control in society necessitated a new division of labor among the political and social forces represented in the corporations, so that ruling families might be able to manipulate them to preserve the status quo and the various backward social arrangements in the tribal, sectarian, and religious establishments. This element makes the monopoly of sources of power and authority in society effective (AlNaqeeb 2014: 108).

Al-Naqib identifies six ways that solidarity is expressed in the Gulf States, and Saudi Arabia in particular (Al-Naqeeb 2014: 148):

1. The tribal institution: Elders with whom the government deals at the local level.

2. Traders: Senior traders and heads of business families who are usually represented by chambers of commerce.

3. Sectarian institutions: Leaders of religious denominations such as Shi'ism, Ibadi, and Zaidi.

4. Religious institutions: Religious leaders represent religious and obedient movements and others.

5. The middle classes: Because professional organizations are prevented from acquiring trade union positions, the government also deals with these middle classes regularly.

6. Foreign workers.

According to Steffen Hertog, solidarity provides an excellent opportunity for the Saudi ruling regime in Saudi Arabia to solidify their decision-making processes from top to bottom:

Corporatism offers the best framework to capture the top-down nature of politics in the Kingdom, the limiting and orchestrating role of state actors, the exclusivity of politics, and the segmentation of group representation through state actors. On an ideational level, too, it corresponds to the consensual ideology of paternally controlled deliberation in Saudi Arabia ("shûrâ") (Hertog 2004). 
The dominance of trade unions may offer the best way to control the nature of the political systems from the top down. Through these unions, we can define the role of government agencies and the uniqueness of political behavior, and the division of trade union representation on state institutions. On an intellectual level, these divisions correspond to the patriarchal authority's ideology in Saudi Arabia, known as "Shura."

Taken together, we can say that one of the most salient features of the decisionmaking process in Saudi Arabia is the central role of the King, who is the final decision-maker. Second, we note the gradual expansion of the functions of other departments in the decision-making process. Since the Saudi Arabian state is usually classified as a rentier state, which depends on the extraction of natural resources as its primary source of income, the state-building process can be explained in the following procedure:

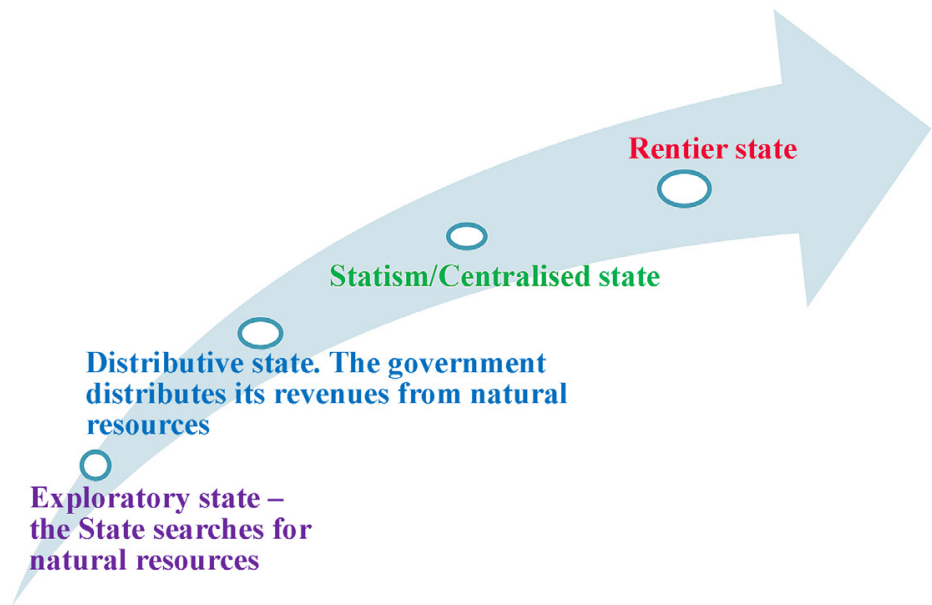

Fig. 4. The anatomy of the Rentier state.

\subsection{The form of the State and its impact on the process of decision-making}

The form and shape of a given state has a radical impact on how it makes decisions. In many places in the Arab world, this is typified by authoritarian structures. The state monopolizes the sources of power and authority in society for the benefit of a ruling elite. ${ }^{1}$

1 We must differentiate between the state and the government. First, according to Aristotle, the state is a social and political unit made up of all citizens and whose goal is to achieve self-sufficiency for all, while the government is the organ that administers the affairs of the state and supervises business within it. Second, Roy Macridis believes that the government is omitting the official institutions that design and implement public policy. Third, according to Timothy Lim, the state is a legal concept based on several conditions: permanent residents, a defined land, and a national government capable of maintaining effective control over its lands. Besides, many scholars believe that the state should be monopolized by the legitimate use of physical force or violence within a particular region. Note that the state's definition includes references to the government, which can be defined as an agency or a body through which a body exercises power and performs its functions. 
The most prominent features of the authoritarian state are (Wilson 2012: 114172):

1. It is not only a system of government but a social system.

2. The state monopolizes the ownership of the means of production.

3. The state seeks to adopt a capitalist system.

4. However, under the auspices of capitalism, the state presents itself as an alternative to its institutions.

5. There is no competition among different ideologies. There is only one ruling ideology.

6. Consumer culture is the behavior of consumers.

Michael Herb classifies the Saudi monarchy as an absolute royal dynastic system. In other words, the King is not bound by a constitution, like in Jordan or Morocco. Family consensus governs the administration of the country. The ruling family also seeks to co-opt figures from outside the family by appointing them to government offices. In this way, the ruling family can "adopt" a network of figures around their central locus of power and offer them to society as technocratic experts and as their representatives (Herb 1991: 10-32). Many offices within the state, however, are also simply filled by members of the royal family.

Importantly, family consensus decides the succession within dynastic monarchies. This consensus-making process entails a great deal of bargaining. The monarch retains and ensures his authority by securing the loyalty of individual family members, specifically sheiks and princes, in return for appointments to senior bureaucratic posts in the state, including positions in the cabinet and within ministries. Highranking family members bargain with the aspiring ruler for these positions, and, in return, they support him. The amount and extent of the bargaining within the family has increased significantly as the state's size has grown following the discovery of oil, as family members vied for leadership posts within new state institutions. The distribution of these and other government positions to members of the royal family and the succession process are essential mechanisms that have enabled the Saudi monarchy to maintain its hold on power (Martorell 2012: 50-51). From this point of view, we can say that the Salafist movement's role in the political decision-making process in Saudi Arabia is complicated, which we will discuss in the next section.

\section{Part two: analyzing the role of the Salafist movement in Saudi decision-making process}

Because religion is one of the essential pillars of the Saudi state and occupies a prominent position in political decision-making, we conclude that Saudi decisionmaking has a profound and long-term impact on the behavior of the Salafist movement. We begin by examining the political situation in the Saudi state between the end of World War II and the end of the 1980s. We explore the influence of successive kings on the behavior and political performance of the Salafist movement by examining the following units: 


\subsection{The institutionalization of the Salafist movement}

King Faisal institutionalized the Salafists and used them in his war against his political opponents. Mohammad Aburumman has used Stéphane Lacroix's book 'Awakening Islam: The Politics of Religious Dissent in Contemporary Saudi Arabia' to identify and clarify the inescapable role of the Saudi state on the Salafist movement:

At a time when the state worked to employ Salafistsm to serve its political interests internally and externally, King Faisal used it to a large extent when a fire broke out between him and Gamal Abdel Nasser, and he was concerned about the latter's speech and the influence of political and intellectual elites in it, as he worked to build the official religious institution, and strengthen the state's religious discourse in the face of the Nasserite discourse, so he established the "Voice of Islam" radio in response to the "Voice of the Arabs" radio, which played a significant role in marketing and promoting Nasser's political speeches as superficial King Faisal established the Muslim World League as a title for Saudi foreign policy directives, in response to Nasser's active participation in the establishment of the non-aligned countries (Aburumman 2013).

With these kinds of moves, King Faisal succeeded in institutionalizing Salafism within Saudi society, controlling it through institutions and with the ruling family benefiting from its utility in fighting hostile forces internally and externally. As a result, Salafism became part of a bureaucratic network of the state and has not posed a violent threat to the state. Until the early 1970s, the Saudi state primarily supported the Islamic awakening.

The 1960s and 1970s witnessed the development in Saudi Arabia of a vast social movement practicing a modern form of Islamic activism that until then has been absent from the country's landscape. This movement was called the Islamic Awakening (al-Sahwa al-Islamiyya), or simply The Sahwa. Relying on the State's own institution, it soon managed to gain a hold over an entire generation of young Saudis. At the same time, more highly structured networks were developed within the Sahwa. Taking advantage of an extremely favorable climate, it soon became a central element of the Saudi social fabric (Lacroix 2011: 37-38).

\subsection{The process of institutionalizing Salafist thought}

The Saudi state tried to fight and contain Nasserite political thought by estabishing colleges and universities in the early 1960s, such as the Islamic University in Madinah in 1961, to compete with Al-Azhar University in Egypt. Nasser wanted to make Egyptian universities a tool to legitimize religious campaigns (Lacroix 2011: 56). Moreover, this approach is considered one method of how the state institutionalized the Salafist movement's thought into Saudi society (Zaccara 2018). 


\subsection{Saudi Arabia and the Muslim Brotherhood}

Saudi Arabia opened its doors to receive many Muslim Brotherhood from Iraq, Syria, and Egypt. It relied on them in institutes and the Islamic University at the beginning of the sixteenth century. The Saudi system benefited from the competencies of these instructors and the graduates they trained. Consequently, according to Stephane Lacroix, an agreement developed between Saudi Arabia and the Muslim Brotherhood to fulfill the following objectives:

First: The Muslimization of the educational curriculum to combat Nasserite political thought.

Second: The monarchy began to establish educational institutions based on the idea of King Faisal's "Islamic modernization," a concept close to the views of the Muslim Brotherhood. Here, we can compare King Faisal and King Abdul Aziz: They both benefited from the reformist thought, but whereas, King Abdul Aziz benefited and relied on the supporters of school reform, King Faisal benefited from the school of the Muslim Brotherhood (Lacroix 2011: 43-44)

Third: The 1960s and 1970s can be characterized by a wide-ranging modernization program for Saudi Arabia's institutions, especially in education. Oil revenues made this modernization possible. However, the Kingdom lacked the technocrats and skilled workers to participate in this process. Wahhabists could not fulfill this role because of their lack of expertise in the physical sciences, and there were only a few supporters of the emerging intelligentsia. Wahabists and the few intellectual Saudis were usually assigned administrative functions and deliberately excluded from educational institutions.

Under these circumstances, it seemed that the members of the Muslim Brotherhood, many of whom had university degrees, were the most wanted candidates for institutional modernization projects, and, in addition, Faisal called for a kind of "Islamic modernization." This concept seemed in many respects close to views of the Muslim Brotherhood (Nehme 1994). Among the most prominent Islamic figures who worked in the field of higher education were Mohammed Sorour Zine El Abidine, who played an essential role in shaping the ideology of the Awakening generation in the 1980s, and Muhammad Qutb, who along with Sarour are among the most critical non-Saudi Islamic personalities in the Kingdom (Al-Saif 2014).

Furthermore, Saudi Arabia asked Muhammad Al-Mubarak to prepare curricula for the colleges of Sharia and education in Mecca and Iraq's Mohammed Al-Sawaf to develop the educational curriculum. Omar Abdul Rahman studied in one of the city landmarks is considered the noblest to kill President Anwar Sadat intellectually relative to the thinking thinker Sayyid Qutb (Qandil 2018).

"just as the attainment of political independence led to the institutionalization

of regionalism instead of pan-Arab integration (Al-Naqeeb 2014: 108)."

Fourth: In the 1970s, Saudi Arabia experienced new economic prosperity due to the oil boom and invested in expanding the dominance and control of the state through appointments to the public sector. 
"Through the mechanism of bureaucratic cooptation, the Saudi state brought society increasingly under its guidance and control in several ways. Employment in the public sector was one such approach. The number of government employees rose as the size of the Government grew. Between 1970 and 1980, the Government established ten new ministries in addition to twenty new government agencies. Accordingly, the Government hired over300,000 public sector employees, increasing the number from 120,000 in 1970. Expanding social services was another method the Government used (Martorell 2012: 63-64)."

This period is also a time of Salafist revival because of the Saudi state's investment in Islamic centers and institutes. Throughout the 1970s, students learned from Egyptian, Syrian, and Iraqi religious professors, which led to the formation of a generational awakening that grew out of the Brotherhood's Salafist ideology.

At the beginning of the 1970s, Saudi Arabia opened its doors to workers from foreign countries, including Egypt. The Kingdom's communities were influenced by the Saudi Salafist ideology and therefore adopted it. When oil prices began to decline in the 1980s, foreign workers began to return to their countries of origin, especially the Egyptians. After they left the Kingdom, these communities took money and ideas with them, which contributed to the export of Salafist ideology (Niblock 2015: 214-235).

\section{The transformation of the relations between the Saudi authorities and the Salafist movement in post-Second Gulf War}

One of the most significant changes to the educational curriculum changes in the Kingdom during the mid-1960s and 1970s was the awakening generation's formation during the 1980s. Implemented under the supervision of members of the Muslim Brotherhood who had fled their countries, these groups married the ideas of the Brotherhood and Salafism. They became an integral part of Salafist Saudi thought. Among the most active groups in the 1980s were Syrian and Qutbist students, which consisted of small but operational and functional groups (Meijer 2009).

The relationship between the Salafist movement of the awakening generation and the Saudi regime was at its height during the 1970s for the following reasons:

First, the Iranian revolution was in its early stages and urged Imam Khomeini to export the Shiite revolution to the Gulf region. One of the most effective means of repelling this influence was to boost Salafist thought because the Salafist ideology utterly rejects Shiism and considers its adherents as Rafidah (Rejectors) (Olsson 2017).

Second, the Saudi regime was not disturbed by the awakening generation, especially during the 1980s. This generation's ideas and beliefs focused on preserving the state's religious identity and combating Westernization and secularization aims the state-supported that. Moreover, the state was mostly satisfied with the Salafists' activities of teaching religious lessons and calling for moral behavior (Al-Khader 2010: 55-65). 
The Saudi regime needed a Salafist-Dawa movement against innovation (Albida' $=$ (البد ) and the call for monotheism because of the confrontations that occurred when Juhaiman al-Otaibi led a group of militants in an attack on Mecca's Grand Mosque in 1979. The intimacy between the Salafists and the Saudi state developed to a point where the state charged the Salafists with running fundraising and recruitment campaigns to support the Afghanistan mujahedeen in its war against the Soviets (Rakowski 2017).

However, the Gulf War became a turning point for this intimate relationship between the Salafists and the Saudi state. For the first time in its history, the Saudi state felt the dangerous possibility of Iraqi occupation, which led the King to invite foreign troops into the Kingdom, which sparked intense opposition from the Salafists (Gharaibeh 2004).

At this point, a clash begins between the Salafist trend (or the awakening generation) and the Saudi regime on an internal level. The roots of this clash are found in the struggle between the new movement (the elders of the awakening) and the old mainstream (the traditional sheiks) within the Salafist movement (Jones 2005). The clash stems in part from the Council of Senior Scholars decision to issue a fatwa authorizing the presence of US forces. Opposition to the fatwa is outlined by Sheikh Safar al-Hawali in his book "Revealing the Sorrow to the Council of Senior Scholars," in which he criticized the shikhs and argued that the US planned to control the region's oil resources. Many in the Western media took the Salafist opposition to be a significant challenge to the Saudi state (Hegghammer 2011: 30-32).

Among the most prominent critics of the monarchy and the Council of Senior Scholars were Salman al-Awda, Safar al-Hawali, and Nasser al-Omar. Al-Awda began to criticize the state's internal and external policies. Al-Omar was among those who strongly criticized the secular and westernized influences that accompanied the US military presence, like the 1990 march demanding the end of the ban on women being able to drive. This protest angered the awakening sheikhs, who considered it a threat to the Kingdom's religious identity (Alshamsi 2012: 78-98). These interactions and fluctuations mark the beginning of the formation of the awakening sheikhs' attempts to organize a reformist Salafist movement separate from the state and demand political, economic, and social reforms.

Meanwhile, another group emerged, centered on reformist intellectuals Muhammad Al-Mas`ari, Saad Al-Faqih, Mohsen Al-Awaji, and Saad Al-Aziz. At the beginning of 1992, they sent a letter in coordination with the awakening sheikhs known as the "Letter of Advice", which outlined their demands for reform in detail. The Council of Senior Scholars issued a violent and strongly-worded response denouncing the letter's proposals, authored by Abdullah bin Jibreen, Abdullah AlMas'ari, and Hammoud Al-Shuaibi (Gaglioti 2013).

This exchange is considered as the beginning of an actual confrontation between the awakening sheiks and the reformist intellectuals on one side and the sheikhs of state institutions. That confrontation led to a rift in Saudi society. The demand for reforms continued until the mid-1990s, taking the form of committees and new institutions. For example, Saudi intellectuals, including Saad Al-Faqih and 
Muhammad Al-Mas'ari, established the Committee for the Defense of Legitimate Rights in 1993. They called on the Saudi authorities to start radical and long-term reforms. Safar al-Hawali, Salman al-Awda, and Nasir al-'Amar were prominent leaders in the awakening generation whose speeches and articles profoundly impacted the movement's direction. During the 1990s, they continued their criticism of the Kingdom's policies, holding debates with their followers to answer the arguments of the sheikhs of the Council of Senior Scholars.

The Council of Senior Scholars pushed back (Aarts 2011), declaring that the formation of committees by intellectuals was illegal and by condemning Al-Faqih, Al-Mas'ari, and Abdullah bin Jubair. This condemnation led to their dismissal from their jobs and their exile to the UK, where al-Faqih founded the Islamic Movement for Reform in Saudi Arabia in 1996 (Sterner 1999). The Saudi security forces imprisoned many awakening sheikhs and intimidated others into silence or prevented them from lecturing (Kostiner 1996).

This state intervention is an essential aspect of the clash between the two sets of sheikhs and religious scholars, with the state becoming a contact line and an essential part of the struggle between the two camps. Between 1994 and 1999, the dynamic of the previous 75 years was turned on its head, with the state turning on its religious sallies in the Salafist movement and working to establish itself as the sole and preeminent power within Saudi society (Alsaif 2013). Al-Hawali, Al-Awda, and Al-Omar were imprisoned for years by the state, which somewhat silenced the Salafist opposition to the state and forced many sheikhs to review their ideas and avoid criticizing the King's policies (Brachman 2008: 53-59).

When the Taliban established its Islamic Emirate, Afghanistan became a safe place for the awakening sheikhs and youth to promote and strengthen their ideas and hone their critiques of the Saudi regime. Saudi dissidents like Ayman Alzawahri, considered a thought leader for the Islamic Emirate, traveled to Afghanistan and Egypt after leaving Saudi Arabia (Hafez 2009).

While attempting to crush the loudest elements of the awakening sheikhs, the Saudi regime was also trying to activate and co-opt a new generation of Salafists. The Council of Senior Scholars did not enjoy much legitimacy from the youth, but was useful as a regime institution. As a result, the state worked to revive the idea of obedience to the guardian of the Two Holy Mosques, which was articulated by university professor Sheikh Muhammad bin Aman al-Jami of the Islamic University, widely known as Al-Jami (Livingstone 2013: 540-542; Wiktorowicz 2006: 213).

These current Salafists are vocally opposed to the awakening sheikhs, rejecting the idea of opposition and accusing the latter of breaking with the ruler. Among those who were taught by Al-Jami was Rabi' bin Hadi al-Madkhali (Zaher 2018). After alAwda and al-Hawali were released from prison, their ideas softened, and they avoided criticizing the King and the regime, advocating morality in Saudi society (Jehl 2001).

Saudi Arabia's policy towards funding and aid for Islamic organizations also changed, again to emphasize the idea of obeying the ruler:

Financial aid has been severely reduced... the Kingdom has implemented new restrictions aimed at limiting private contributions 
to what it considers Islamic groups. A new policy was enacted in 1993 when the Government announced that only organizations sanctioned by the Ministry of Interior could receive donations (Wilson and Graham 1994: 135)

On the external level, the Saudi regime changed its policies towards many Islamic countries; for example, Saudi Arabia severed its relationship with Yemen. Its relations with Jordan were weak and cold. In contrast to Yemen and Jordan, Saudi Arabia changed its relationships and policies towards Egypt, Syria, and Morocco to become strong. Saudi Arabia's policy towards non-Arab Islamic countries such as Malaysia and Indonesia also changed through the Islamic organization because they did not condemn the State of Iraq in the 1990s. As for the countries like Pakistan and Bangladesh, they were part of the international coalition, so they were among the Saudi regime's countries.

\section{Conclusion}

In conclusion, since its inception, the Salafist movement was and is still under the influence of the political process. Political and social changes significantly influenced the behavior of this movement. In many cases, we find that the Salafists in Saudi Arabia based their political views on directed policies.

In our research, we took a look at the history of the Salafist movement from after World War II until the mid-1990s. In the decades after World War II and the Kingdom's emergence on the world stage, Saudi Arabia faced harsh criticism internally from nationalists and used Salafist ideology to combat nationalist influences. The stateSalafist relationship was mutually beneficial and continued amicably until the 1990s when it soured largely over foreign troops in the Kingdom, which the Salafists considered a violation of Sharia law. For the Saudi state, seeking help from foreign forces is a political matter without Salafist opinions on the matter. The state then used the security forces to clamp down on the Salafist sheikhs, particularly those associated with the awakening generation.

The process of the Saudi regime's influence on the political views of the Salafist movement can be summarized with the following points:

1. The Saudi state first succeeded in institutionalizing religion in Saudi society and established the Council of Senior Scholars as an official religious institution affiliated with the State. It then used the education system and universities to further influence and socialize Salafist thought not to interfere in political affairs.

2. The State extended its control over all state institutions, including its religious and intellectual institutions.

3. Saudi Arabia benefited from Salafist ideology, using it to confront nationalist thought after World War II.

4. Salafists controlled the curriculum in cooperation with the state. This cooperation continued until the beginning of the arrests of the awakening sheikhs. After that, many of them were excluded from administrative and educational positions. 
Address:

Kardo Rached

Middle East Institute

Sakarya University

Serdivan, Sakarya, Turkey

University of Human Development

Sulaimaniyah, Iraq

E-mail: kardo.rached@uhd.edu.iq

\section{References}

Aarts, Paul (2011) "Maintaining authoritarianism: the jerky path of political reform in Saudi Arabia". Journal of Orient 52, 1. Available online at $<$ https://dare.uva.nl/search?identifier=f7626f53$1 \mathrm{a} 0 \mathrm{f}-4 \mathrm{f} 56-8 \mathrm{c} 0 \mathrm{e}-9 \mathrm{~b} 36 \mathrm{e} 3 \mathrm{~d} 31 \mathrm{dd} 0>$. Accessed on 28.04.2021.

Abdulhay, Waleed et al. (2010) How the decision is made in the Arab regimes: a case study. JordanAlgeria-Saudi Arabia-Sudan-Syria-Iraq-Kuwait-Lebanon-Egypt-Morocco-Yemen. Beirut: The Center for Arab Unity Studies. (In Arabic.)

Aburumman, Mohammad (2013) Salafism in the Arabian Peninsula. (In Arabic.) Available online at $<$ https://www.academia.edu/15296830/>. Accessed on 28.04.2021.

Al-Khader, Abdul Aziz (2010) Saudi Arabia, the biography of a state and a society. Beirut: Arab Network for Research and Publishing. (In Arabic.)

Al-Naqeeb Khaldoun Hassan (2014) Society and state in the Gulf and Arab Peninsula: a different perspective. London: Routledge.

Alsaif, Tawfiq (2013) "Relationship between state and religion in Saudi Arabia: the role of Wahabism in governance". Contemporary Arab Affairs 6, 3, 376-403.

al-Saif, Tawfiq (2014) "Political Islam in Saudi Arabia: recent trends and future prospects". Journal Contemporary Arab Affairs 7, 3, 398-420.

Alshamsi, Mansoor Jassem (2012) Islam and political reform in Saudi Arabia: the quest for political change and reform. London: Routledge.

Brachman, Jarret M. (2008) Global Jihadism: theory and practice. London: Routledge.

Gaglioti, Angelo Roberto (2013) The liberal and radical protests in mid-90s Saudi Arabia politics. London: The Research Centre for the Mediterranean Relations. Available online at $<\mathrm{http}: / /$ www.medalics.org/wp-content/uploads/2013/03/TR-4-The-liberal-and-radical-protests-inmid-90s-Saudi-Arabia-politics.pdf $>$. Accessed on 28.04.2021.

Gharaibeh, Ibrahim (2004) The two issues Salafi and Shiite in Saudi Arabia. (In Arabic.) Available online at $<$ https://www.aljazeera.net/opinions/2004/10/3/\%D8\%A7\%D9\%84\%D9\%85\% D8\%B3\%D8\%A3\%D9\%84\%D8\%AA\%D8\%A7\%D9\%86-\%D8\%A7\%D9\%84\%D8\%B 3\%D9\%84\%D9\%81\%D9\%8A\%D8\%A9-\%D9\%88\%D8\%A7\%D9\%84\%D8\%B4\%D9\%8A\%D8\%B9\%D9\%8A\%D8\%A9-\%D9\%81\%D9\%8A>. Accessed on 28.04.2021.

Hafez, Mohammed M. (2008) "Jihad after Iraq: lessons from the Arab Afghans". Studies in Conflict \& Terrorism 32, 2, 73-94.

Hegghammer, Thomas (2011) Jihad in Saudi Arabia: violence and Pan-Islamism since 1979. London: Cambridge University Press. 
Herb, Michael (1991) All in the family: absolutism, revolution, and democracy in the Middle Eastern monarchies. (SUNY Series in Middle Eastern Studies.) Albany: State University of New York Press.

Hertog, Steffen (2004) "Building the body politic: emerging corporatism in Saudi Arabia". Arabian Humanities. DOI: https://doi.org/10.4000/cy.187

Hourani, Albert (1992) A history of the Arab peoples. New York: Warner Books.

Insight \& Analysis (2012) Egypt's Islamists: a growing divide. The Wilson Center. Available online at <https://www.wilsoncenter.org/article/egypts-islamists-growing-divide>. Accessed on 28.04.2021.

Jehl, Douglas (2001) “A nation challenged: a critic; after prison, a Saudi Sheik tempers his words". The New York Times, December 27. Available online at $<$ https://www.nytimes.com/2001/12/27/ world/a-nation-challenged-a-critic-after-prison-a-saudi-sheik-tempers-his-words.html>. Accessed on 28.04.2021.

Jones, Toby Craig (2005) "The clerics, the Sahwa and the Saudi state". Strategic Insights 4, 3. Available online at $<$ https://www.hsdl.org/?view\&did=453693>. Accessed on 28.04.2021.

Khatab, Sayed (2011) 'Wahhabism'. Understanding Islamic fundamentalism: the theological and ideological basis. Cairo: American University in Cairo Press.

Kostiner, Joseph (1996) "State, Islam and opposition in Saudi Arabia: the post-desert storm phase". Terrorism and Political Violence 8, 2, 75-89. DOI: https://doi.org/10.1080/09546559608427347

Lacroix, Stéphane (2011) Awakening Islam: the politics of religious dissent in contemporary Saudi Arabia. Massachusetts: Harvard University Press.

Livingstone, David (2013) Black terror white soldiers: Islam, Fascism \& the New Age. S.1.: Sabilillah Publications.

Martorell, Benjamin E. (2012) Oil, politics, society and the state in the Middle East: enduring authoritarianism in Iran and Saudi Arabia. Master Thesis. Chicago, Illinois: DePaul University, College of Liberal Arts \& Social Sciences.

Meijer, Roel (2009) Global Salafism: Islam's new religious movement. London: Oxford University Press.

Nehme, Michel G. (1994) “Saudi Arabia 1950-80: Between Nationalism and religion”. Middle Eastern Studies 30, 4, 930-943.

Niblock, Tim (2015) State, society and economy in Saudi Arabia. London: Routledge.

Olsson, Susanne (2017) "Shia as internal others: a Salafi rejection of the 'rejecters"'. Journal Islam and Christian-Muslim Relations 28, 4, 409-430.

Qandil, Mohamed Mokhtar (2018) "The Muslim Brotherhood and Saudi Arabia: from then to now". Fikra Forum. Available online at $<$ https://www.washingtoninstitute.org/fikraforum/view/themuslim-brotherhood-and-saudi-arabia-from-then-to-now $>$. Accessed on 28.04.2021.

Rakowski, Stephen (2017) How the 1979 Siege of Mecca haunts the House of Saud. Available online at $<$ https://worldview.stratfor.com/article/how-1979-siege-mecca-haunts-house-saud $>$. Accessed on 28.04.2021.

Shahrour, Izzat (2013) Chinese decision-making ... its centers and development (in Arabic) Available online at <https://studies.aljazeera.net/ar/issues/2013/11/201311137631298783.html>. Accessed on 28.04.2021.

Sterner, Michael (1999) "Saudi Arabia and the politics of dissent, by Mamoun Fandy". Middle East Policy 6, 4, 200. 
Wictorowicz, Quintan (2006) “Anatomy of the Salafi Movement”. Studies in Conflict \& Terrorism 29, 3, 207-239.

Wilson, Peter W. and Douglas F. Graham (1994) Saudi Arabia: the coming storm. London: Routledge. Wilson, Rodney (2012) Economic development in the Middle East. London: Routledge.

Yan, Xing (2015) "Analysis of political decision-making and its influencing factors". Cross-Cultural Communication 11, 3, 42-46.

Zaccara, Luciano (2019) “Kuwait Islamists: from institutionalized to informal opposition". International Studies Journal 15, 4, 75-98.

Zaher, Moutaz (2018) “The armed Madkhali movement. Ruya for Research and Studies". (In Arabic.) Available online at $<$ https://ruyaa.cc/Page/4814/>. Accessed on 28.04.2021. 